Canadian University Music Review

Revue de musique des universités canadiennes

\title{
Leonora Unbound: Tonality as Allegory
}

\section{Murray Dineen}

Volume 20, numéro 1, 1999

URI : https://id.erudit.org/iderudit/1015646ar

DOI : https://doi.org/10.7202/1015646ar

Aller au sommaire du numéro

\section{Éditeur(s)}

Canadian University Music Society / Société de musique des universités canadiennes

\section{ISSN}

0710-0353 (imprimé)

2291-2436 (numérique)

Découvrir la revue

Citer cet article

Dineen, M. (1999). Leonora Unbound: Tonality as Allegory. Canadian University Music Review / Revue de musique des universités canadiennes, 20(1), 22-40.

https://doi.org/10.7202/1015646ar
Résumé de l'article

Tonality has both a literal and a figurative or allegorical aspect. Tonal unity, a commonplace among much current music theory, is a superficial entity, a literal facade beneath which lies a sustained and discursive domain, where tonality is made and remade in a continual process of fracturing and reinterpretation. Like the frought persona of Beethoven's Leonora-cum-Fidelio, the tonality of the aria "Abscheulicher! ... Komm Hoffnung ..." defies analysis as a unified structural whole. Like the behaviour of the piano teacher in Bonnie Burnard's short story "Music Lessons," the conventional behaviour of tonality can be seen to crack and buckle in the aria, albeit only briefly, before it is smoothed over and fractious elements suppressed behind a facade of the calibre of a Fidelio.
All Rights Reserved (C Canadian University Music Society / Société de musique des universités canadiennes, 2000
Ce document est protégé par la loi sur le droit d'auteur. L'utilisation des services d'Érudit (y compris la reproduction) est assujettie à sa politique d'utilisation que vous pouvez consulter en ligne.

https://apropos.erudit.org/fr/usagers/politique-dutilisation/ 


\title{
LEONORA UNBOUND: TONALITY AS ALLEGORY
}

\author{
Murray Dineen
}

My very chains and I grew friends,

So much a long communion tends

To make us what we are:-even I

Regain'd my freedom with a sigh.

Lord Byron, The Prisoner of Chillon

This essay takes as point of departure the thesis that tonality is two-dimensional, with fixed and fluid aspects-a fixed, literal aspect, and a fluid and figurative or allegorical aspect. ${ }^{1}$ Tonality comprises two domains accordingly: a superficial structural domain built of clear and unambiguous pitch relations reckoned to one definitive tonal centre and confined to the literal surface of a musical work; and a domain of deeper and less tangible import, of shifting and figurative relations that reflect tonality's making and remaking. The figurative domain forms a kind of allegorical shadow behind the surface of musical works. Tonal allegory is the subject of this essay.

The literal side of tonality presupposes a formal, putative "organic" unity wherein all the various concrete facets of a musical work are linked in one ultimate and finite state of wholeness through the relationship of all pitchesindeed of all pitched musical phenomenon - to one referential pitch, the tonic or tonal centre. This unitary thesis of tonality or its derivatives is to be found in theorists and music scholars as diverse as Fétis, Castil-Blaze, d'Indy, Riemann, Hermann Mendel, Kurth, Schoenberg, and Schenker. For Fétis, tonality is a unitary principle governing the

1 The notion of allegory applied or proper to music is addressed in a remarkable article by Alan Street: "Superior Myths, Dogmatic Allegories: The Resistance to Musical Unity," Music Analysis 8, nos. 1-2 (1989): 77-123. In its breadth of scope and critical force, Street's work is unequalled and unprecedented, especially in its treatment of allegory, which is defined in a sense critical of myths such as "unity." In this regard Street adopts a post-structuralist position, quite unlike that of Julie Brown, in "Schoenberg's Musical Prose as Allegory," Music Analysis 14, nos. 2-3 (1995): 161-91, which reverts largely to a structuralist model of formal unity. Kevin Korsyn, in "Towards a New Poetics of Musical Influence," Music Analysis 10, nos. 1-2 (March-July 1991): 3-72, dramatically misunderstands the nature of post-structural thought as it surfaces in Street's article. He suggests that "Street's conclusions might seem to lead music theory to an impasse: how can one analyze music if one rejects the idea of autonomous, self-contained compositions?" Street's notion of allegory would, it ought to be said, lead music theory out of the impasse of the idea of autonomous, self-contained compositions. See as well Alan Street, "Narrative and Schoenberg's Five Orchestral Pieces, op. 16," in Theory, Analysis and Meaning in Music, ed. Anthony Pople (Cambridge: Oxford University Press, 1994), 164-83. 
ordering of the notes of the scale, in their respective distances and their harmonic relations. The composition of chords, the circumstances under which they are modified, and the laws of their succession are the necessary results of this tonality. Change the order of notes, or change their distances, and the majority of harmonic facts are reduced to nil. ${ }^{2}$

This idea of certain necessary consequences should tonality be altered underpins the unitary aspect of Fétis's tonality. Nothing can be altered without some consequence:

That which I call tonality is thus the order of melodic and harmonic givens resulting from the disposition of the intervals between the notes of our major and minor scales. If even one of these intervals is inverted, the tonality takes on another character, and completely different givens manifest themselves in the harmony. ${ }^{3}$

In the Traité complet, tonality is defined as the "necessary relations" [iii], the "principal regulator of the relations of notes ..." [vii], with immediate consequences for the "creation of beauty" [xiv]. In concrete terms, tonality is premised in the unity of the natural chord of the fundamental and its derivative, the perfect [major] chord of which all other chords are but modifications: "With the natural chord, fundamental and derived, tonality is completely established and the faculty of modulation exists. Other harmonic groups that could affect the ear are but modifications of these natural chords" (section 364). Fétis speaks of "tonal unity" in several senses in this treatise, which correspond to various tonal orders. ${ }^{4}$

For Castil-Blaze, in the concise definition of tonalite in the Dictionnaire, tonal unity is implied in the necessary wholeness and integrity of the tonality. The sense of a given tonality is annulled once its essential properties are transferred to other pitches (giving rise to the sense of another tonality):

Tonality[:] ... property of mode, which exists in the use of its essential notes ... The octave, the fifth, and the fourth from the first note of the mode are tonal intervals, but they cease to have that property the moment that one uses them on the second, third, and sixth note of the mode; given that these notes arise as tonal notes, they cannot be considered as generators without giving implicitly the idea of a new mode. 5

2François-Joseph Fétis, Esquisse de l'histoire de l'harmonie considerée comme art et comme science systématique (Paris: Bourgogne et Martinet, 1840), 167-68. Translations in this paper are the author's unless otherwise noted.

3Fétis, Esquisse de l'histoire de l'harmonie, 169.

4 Fétis, Traité complet de la théorie et de la pratique de l'harmonie ... (Paris: Brandus, 1875). His notion of the tonal orders called "pluritonique" and "omnitonique," and their relation to tonal unity is particularly problematic (see Livre troisième, chapitres III, IV), since it is tied to a model of perfection and decay (compare section 284, for example).

5François-Henri-Joseph Castil-Blaze, Dictionnaire de musique moderne, 2nd ed. (Paris: Adrien Egron: 1825), s.v. “Tonalité.” 
Castil-Blaze calls this the "tonal force of the first, fourth, and fifth notes of the mode," meaning a unifying referential quality that determines the mode, its essential chords, and its accessory harmonies.

D'Indy's unitary definition of tonality is that of a structuralist: "Tonality can be defined thus: that group of musical phenomena which human listening is able to appreciate by direct comparison with a constant phenomenon-the tonic-taken as an invariable term of comparison." 6 The tonic, accordingly, is "the common measure necessary for determining the relative value of all phenomena occurring in a musical fragment."

For Hugo Riemann, unitary tonality entails "the individual meaning that chords carry according to their relationship to a principal note, the tonic." The new study of harmony, according to Riemann, "is none other than the study of the meaning of chords for the logic of composition ... So the C-major tonality prevails as long as the harmony is understood according to their relation to a C-major chord."7

Mendel's influential Musikalisches Conversations-Lexicon treats the concept of tonality under the widened unitary rubric of key or Tonart: "Key ... we call the particular ordering according to which artistically applied tones are employed with constant reference to a given fundamental." The formal role played by key-tonality-is stressed by Mendel: "The significance of the modern key is ... it enables first the unified artistic form." 8

Ernst Kurth's conception of tonality is grounded in the unitary formal relationship to a tonic: "Tonality signifies the unitary relation of sounds to a central tonic, and carries two principles: first, the existence of adjoining discrete moments, and secondly the existence or at least the reconstructability of a tonal centre." 9

A typical formalist definition is Schoenberg's: "We shall probably have to define tonality as the art of combining tones in such successions and such harmonies or successions of harmonies, that the relation of all events to a fundamental tone is made possible." 10

It is not possible to render an exact equivalent to tonality in Schenkerian terms, since the principle of reference to one sounding point-be it the chord in nature, or the fundamental-entails elements of differing kind, the notion

\footnotetext{
6 Vincent d'Indy, Cours de composition musicale, 5th ed., Premier livre (Paris: Durand, 1912), 108.

7Hugo Riemann, Musiklexicon, 3rd ed. (1887), and 8th ed. (1916), s.v. "Tonalität."

8Hermann Mendel, Musikalisches Conversations-Lexicon, eine Encyklopaedie der gesammten musikalsichen Wissenschaften ... (Leipzig: List and Francke, [1883]), vol. 2, s.v. "Tonart."

9Ernst Kurth, Romantische Harmonik und ihre Krise in Wagners "Tristan" (Bern: P. Haupt, 1920), 306.

10"Problems of Harmony," in Style and Idea: Collected Writings of Arnold Schoenberg, ed. Leonard Stein, trans. Leo Black (Berkeley: University of California Press, 1984), 275-76. Although Schoenberg does make varied reference to tonality in his writings, a synthesis of his thought on the subject ought to include the notion of a tonal problem, a synthesis seldom achieved in his writings. See Patricia Carpenter, "Grundgestalt as Tonal Function," Music Theory Spectrum 5 (1983): 15-38; and P. Murray Dineen, "Problems of Tonality: Schoenberg and the Concept of Tonal Expression" (Ph.D. diss., Columbia University, 1988), 89.
} 
of composing out, the procedures of strict counterpoint, a structure of distinct but interrelated levels. The telos of tonality, however, is much the same in its Schenkerian traces as it is in the theorists cited above-a unitary, synthetic conception of a musical work, a unity displayed in the multifaceted and complementary forms of its composing out. ${ }^{11}$

Tonality conceived thus, by these and other theorists, provides a kind of concrete exemplar for the thesis of organic unity espoused in some aesthetics of music, that every aspect of a musical work relates organically to every other aspect of the work by means of reference to one tonal centre. ${ }^{12}$

The figurative side of tonality undercuts this unitary assumption, effacing it. As we shall see, in figurative tonality there are no fixed and finite states, no seamless formal unities, but instead states of sustained and fundamental fracturing and reinterpretation. ${ }^{13}$ Tonality is not fixed and flawless but filled with contradictions in a second domain, that of allegory.

11 The term Tonalität does not figure extensively in Schenker's writings. (At its most copious, in certain graphs from Das Meisterwerk in Musik, the term prefaces the underpinning of Roman numerals.) Schenker, instead, seems to prefer the term Tonart and the concept of the scale degree in his Harmonielehre. See Oswald Jonas's commentary in Schenker's Harmony, ed. Jonas, trans. Elisabeth Mann Borgese (Cambridge: M. I. T. Press, 1973), xxi-xxii. In his Free Composition, Schenker applies the term to the foreground of a musical work as opposed to the background, which he calls "diatony"; see: Free Composition, vol. 3 of New Musical Theories and Fantasies, ed. and trans. Ernst Oster (New York: Longman, 1979), 5.

12For classic definitions of organicism and musical unity - and of tonality explicitly or implicitlysee Heinrich Schenker, "Vom Organischen der Sonatenform," Das Meisterwerk in der Musik, Band II (Wien: Drei Masken Verlag, 1926): 45-54; Harmony, 244-45, 293-94, and passim [Schenker's organic metaphor in Harmony is one of vitalism and procreation]. See also Schoenberg, Theory of Harmony, trans. R. Carter (Berkeley: University of California Press, 1983), 53, 289, and 311 in particular, and see 28-29, 81, 151-52, 270; and Schoenberg, Fundamentals of Musical Composition, ed. Gerald Strang, with Leonard Stein (London: Faber and Faber, 1967), 1; Schoenberg, "The Relationship to the Text," in Style and Idea: Selected Writings, 144.

An oft-cited definition of organicism is Ruth Solie's "The Living Work: Organicism and Musical Analysis," Nineteenth-Century Music 4(1980-81): 147-56. See as well David Montgomery, "The Myth of Organicism: From Bad Science to Great Art," The Musical Quarterly 76, no. 1 (Spring 1992): 17-66; and Lotte Thaler Organische Form in der Musiktheorie des 19. und beginnenden 20. Jahrhunderts (Munich: Katzbichler, 1984).

On Schoenberg's organicism, see Patricia Carpenter, “A Problem in Organic Form: Schoenberg's Tonal Body," Theory and Practice 13 (1988): 31-63; and Severine Neff, "Schoenberg and Goethe: Organicism and Analysis," in Music Theory and the Exploration of the Past, ed. C. Hatch and D. Bernstein (Chicago: University of Chicago Press, 1993), 409-33. Among recent writings about Schenker and organicism, see Robert Snarrenberg, "Competing Myths: The American Abandonment of Schenker's Organicism," in Theory, Analysis and Meaning in Music, 29-56; Gary W. Don, "Goethe and Schenker," In theory only 10, no. 8 (1988): 1-14; William Pastille, "Music and Morphology: Goethe's Influence on Schenker's Thought," in Schenker Studies, ed. Hedi Siegel (Cambridge: Cambridge University Press, 1990), 29-44. See as well William Pastille, "Ursatz: The Musical Philosophy of Heinrich Schenker" (Ph.D. diss., Cornell University, 1985); and Michael Cherlin, "Hauptmann and Schenker: Two Adaptations of Hegelian Dialectics," Theory and Practice 13 (1988): 115-31. A more problematic discussion of Schenker's organicism is found in Richard Littlefield and David Neumeyer's "Rewriting Schenker: Narrative-History-Ideology," Music Theory Spectrum 14, no. 1 (Spring 1992): 38-65.

13The identification of such states in literary studies has become commonplace in the last thirty years. The effect of literary studies on music theory has only recently been felt, however, and not always with the profundity characteristic of the revolution in literary criticism effected by post-structural and 
The term allegory denotes not only a type of parable or moral tale-a simple story or narrative that connotes or otherwise carries with it a second, abstract narrative, a moral or lesson. ${ }^{14}$ Allegory means as well the principle carried out in such "allegories," that of a sustained state of reinterpretation and rereading, a principle thought to be implicit in semiosis and honoured in much recent criticism of the arts. As Walter Benjamin described it, "Allegory ... is not a playful illustrative technique, but a form of expression, just as speech is expression, and, indeed, just as writing is." 15 Tonality, accordingly, is not merely a simple story, narrative, or drama (the story of a work's organic unity, for example) to be taken at face or literal value. ${ }^{16}$ Behind every simple tonal

deconstructive studies in the 1960s. See Robert Samuels, "Derrida and Snarrenberg," In theory only 11, nos. 1-2 (1989): 49-50, 52, 55. (On p. 52, Samuels locates the play or effect of différance [after Derrida] "within the tonal conventions," and it is this implicit fracturing in tonal convention that I am after in this paper.) And see Adam P. Krims, "Bloom, Post-Structuralism(s), and Music Theory," Music Theory Online 0, no. 11 (November 1994): 1.2, 2.2-3, 2.6-7; the response by Joseph N. Straus, "Post-structuralism and Music Theory (A Response to Adam Krims)," Music Theory Online 1, no. 1 (January 1995): 5; and Krims's reply, "On the Fear of Losing Our Tools (A Response to Joseph N. Straus)," Music Theory Online 1, no. 1 (January 1995): 4.1-3. Straus seems unwilling to subject certain apriories"pitch-class transposition ... the subdominant harmony"- to scrutiny, and a reticence of this sort is to be found in a growing response to post-structural thought in music scholarship: see Kofi Agawu, "Analyzing Music Under the New Musicological Regime," Music Theory Online 2, no. 4 (May 1996) 1-22; Peter van den Toorn, review of Jonathan Dunsby, Models of Musical Analysis: Early TwentiethCentury Music, in Music Analysis 14, nos. 2-3 (1995): 340-43, 351.

For an accurate appraisal of music theory's relation to deconstruction, see Adam Krims, "Disciplining Deconstruction (For Music Analysis)," 19th-Century Music 21, no. 3 (Spring 1998): 297-324.

Among other writings questioning the primacy and unity of analytic practice see Richard Littlefield and David Neumeyer's "Rewriting Schenker: Narrative-History-Ideology." The article is problematic in several regards (not the least of which being the disclaimers of Schenker's intellectual responsibility, on p. 48, which are most disconcerting). While invoking the principal texts of post-structuralist thought (pp. 38-41), the authors ignore the elements of disruption and reinterpretation patent therein. Their linking of ideology and structuralist dogma in music theory is ground breaking (pp. 41-42), but the implications of ideology upon the ontology of structuralist analysis are largely ignored in their analysis; the analytic results of their readings and rereadings of Czerny and Schenker repeat the structuralist model of unity. They do, however, confess to "impose" Schenkerian stylistic codes on Czerny's work, a thread left unravelled unfortunately, as the recognition of imposing codes would be of some import to a post-structuralist sense of music criticism.

14 "A figurative representation conveying a meaning other than and in additional to the literal ... distinguished from a metaphor by being longer sustained and more fully carried out in its details, and from an analogy by the fact that the one appeals to the imagination and the other to the reason." The Encyclopaedia Britannica, 11th ed., s.v. "Allegory." And see "Allegory" in Patrick Murray, Literary Criticism: A Glossary of Major Terms (New York: Longman, 1978), 1-9. "An essential feature of allegory is that it is to be interpreted point by point. Every feature must represent something else. Allegory has been aptly compared to a description in code, always prompting the reader to ask what the persons or articles or events in the story stand for." See as well: "Medieval Theory and Criticism," The Johns Hopkins Guide to Literary Theory and Criticism, ed. M. Groder and M. Kreiswirth (Baltimore: Johns Hopkins University Press, 1994), 501-2.

15 Walter Benjamin, The Origin of German Tragic Drama, trans. John Osborne (London: N.L.B., 1977), 162. See also Paul de Man, Blindness and Insight: Essays in the Rhetoric of Contemporary Criticism (New York: Oxford, 1971); idem, Allegories of Reading: Figural Language in Rousseau, Nietzsche, Rilke, and Proust (New Haven: Yale University Press, 1979); Tzvetan Todorov, Introduction à la littérature fantastique ([Paris]: Éditions du Seuil, 1970), 67.

16 See the references to Schoenberg and to Donald Francis Tovey as theorists employing dramatic models in Fred Everett Maus, "Music as Drama," Music Theory Spectrum 10 (1988): 70, 73. 
story lies a second, abstract narrative, redolent with multiple interpretations. The task of this paper is to postulate tonal allegory and to illustrate it with respect to an aria and recitative from Beethoven's opera Fidelio.

In allegory, figurative meanings have literal counterparts, much as gluttony, a common and complex vice in humanity, has a simple literal counterpart, Gluttony, in Marlowe's Doctor Faustus, or much as the haste with which mortal end finds humans unprepared has as allegorical counterpart, the arrival in great haste of God's messenger Death in the medieval morality play Everyman. The challenge of reading and analysis-and likewise listening and analysis-is to tease apart the relation of the figurative to the literal.

Distinguishing the literal from the figurative in music is not a slight task, although in many respects it lies at the heart of modern music theory. Customarily, in analytic music theory we uncover sound structures represented literally by score notation, and we alter such notations into voice-leading graphs or motivic tables. ${ }^{17}$ Although such analyses are commonly taken to represent the music itself, and thus to represent music literally, the tradition of analysis in our century carries, alongside with its literal pretensions, a more figurative domain.

Among the modern masters of tonal allegory surely Heinrich Schenker must be numbered-Schenker, who likened the life of a motive to that of a human being:

For what is the fundamental purpose of the turns and tricks of the cyclical form? To represent the destiny, the real personal fate, of a motif or of several motifs simultaneously. The sonata represents the motifs in ever changing situations in which their characters are revealed, just as human beings are presented in a drama. ${ }^{18}$

In a similar sense Arnold Schoenberg compared tonality to the travails of a dominion, with its central seat of power, the tonic, and rebellious outlying "regions." 19 In the writings of these two theorists, the metaphoric and its figurative domain are sustained at some length, so much so that we discern a second "story" or tale-often with ethical and moral overtones-at work. The plots of these tales inevitably take as conceit some state of gross misunderstanding on the part of German and Austrian musicians and theorists, and at a more figurative domain a collective, organic misunderstanding on the part of a society or a nation-Vienna or Germany. ${ }^{20}$ The contemporary confused state of affairs is resolved into clarity only when tonal unity is revealed as an a priori

17This is called "technical analysis" by Nicholas Cook in A Guide to Musical Analysis (London: J. M. Dent, 1987), 12. The literal aspect of several analytic approaches is addressed in Pople, "Systems and Strategies: Functions and Limits of Analysis," in Theory, Analysis and Meaning in Music, 115-20.

18 Schenker, Harmony, 6; see also 3-44 passim.

19Egotism [Egoismus] and vitalism figure prominently in Schoenberg's description of the relations among members of a tonality; see Theory of Harmony, 77, 116, 128, 150-51, 369-70.

20 See Schenker, Free Composition, 8-9, and Schoenberg, Theory of Harmony, 7-17. 
by these authors, in their struggle to overturn the errors of less incisive theorists, and here we must note that allegory - as it is avowed, espoused, or merely revealed by theorists-is sometimes self serving. The allegorical in both Schenker's and Schoenberg's work takes the form of asides or polemics and is sometimes exiled to appendices in recent editions. ${ }^{21}$

Despite the allegorical thread linking the travails of tonal unity to the travails of a human or a nation, neither theorist created a truly modern allegory of tonality. By modern allegory we mean an extended, discursive relationship drawn between literal and figurative tonal worlds, a domain of relation that is not bounded by any ultimate sense of unity or definition. For Schoenberg and Schenker, unity is both telos and pale. Our modern sense of allegory does not accommodate such ultimate unities. Allegory, like the play of meaning in general, is open-ended, for its stories, both literal and figurative, are subject to constant redefinition and reinterpretation. Modern allegory is contradiction and rereading incarnate.

The task of tracing the allegories of modern tonal theory lies beyond the scope of this essay. Here I shall merely sketch the outlines such a study might take by comparing tonality with two more contained allegories: the Leonoraas-Fidelio trouser role as it crystallizes in the aria "Abscheulicher! ... Komm Hoffnung ... Ich folg' dem innern Triebe" [hereafter "Komm Hoffnung"], from Beethoven's Fidelio, and a short story by a Saskatchewan writer, Bonny Burnard, entitled "Music Lessons."22 The aria from Fidelio will prove particularly important, since the allegory uncovered in the libretto can illuminate the allegory in the aria's tonality, if not tonality in general. The type of allegory at work here we might call reversal, ironic reversal: literal and figurative are dramatically opposite tendencies; the stronger a particular interpretation tends toward the literal, the stronger it leans simultaneously toward its figurative counterpart. ${ }^{23}$ Given the progressive deterioration of her situation in the course of the first act, Leonora's rescue project seems but a hair's breadth from being wrecked upon the shoals of misfortune. Fidelio on the other hand encounters mounting successes, so much so as to convince us that the deception might just be carried off. Leonora's persona appears progressively more riddled with fissures, directly in converse proportion to the smoothness of the facade her trousered alter ego Fidelio presents. Therein lies the irony of the allegory: Fidelio's literal successes are all figurative of Leonora's growing desperation.

These antipodes-Fidelio's developing success, Leonora's immanent folly-provide (albeit only fortuitously) a foil with which to consider a central tenet of tonality, structural unity. Structural tonal unity, like Fidelio, is a fiction. Like Fidelio, the more a tonality would seem to master the guise of unity, the more we are reminded of the desperate frailty of the project. Many

21 See Robert Snarrenberg, "Competing Myths: The American Abandonment of Schenker's Organicism," 29.

22Bonnie Burnard, "Music Lessons," in Women of Influence (Regina, Sask.: Coteau Books, 1989), 13-18.

23Todorov's Introduction à la littérature fantastique contains many typologies of the weakness or relative strength of literal and figurative aspects of allegory, which serve as models here. 
works of great tonal strength (consider the late symphonies of Bruckner and Mahler) could be said to balance tonal centricity and unity with opposing tendencies of tonal disruption and dissolution. ${ }^{24}$ Under the rubric of ironic allegorical reversal, the question arises: How can one analyze as a unified structure the tonality of an aria like "Komm Hoffnung," without considering opposing tendencies toward tonal disunity? This paper assumes no necessary relation of text to musical score, but given a libretto filled with superficial successes but riddled with hidden character contradiction and tension, the ability to analyze the aria's tonality as unitary entails an accomplished myopia. Ultimately the tonality of the aria leads discursively to a fraught question: How can one analyze any work embodying tonality as a unified structural whole without creating a fiction of the calibre of Fidelio?

The term allegory, to reiterate, means for us not only of a proverbial story, where behind one tale lies another, the two related as literal and figural, as in the Everyman morality plays, Marlowe's Doctor Faustus, Piers Plowman, Spenser's poetic allegory Faerie Queene, or Bunyan's Pilgrim's Progress. Allegory is also a mode or operation present in many other literary types. Were allegory defined in the narrow canonic sense of a literature, the role Leonoracum-Fidelio would bear no allegorical content. But there are two elements that elevate the Leonora-Fidelio role above that of a mere costume deception.

The first element is the sustained and discursive relationship between two stories-Leonora's and Fidelio's. The sustained and discursive relationship is particularly important to allegory, distinguishing it from its more rigid counterpart, the realm of the symbolic. ${ }^{25} \mathrm{~A}$ symbol is a rigid entity; fixed and inflexible, it does not bend with time or telling. Marlowe's characters, however, are anything but rigid. Being part of a drama, they interact with Faust and among themselves, and in doing so they transform, inflecting each other in such a way as to make the human condition a dynamic story of condemnation and rescue-a literal tale of characters and a figurative tale of morals. Marlowe's ability at sustaining these literal and figurative domains in counterpoint elevates his work above the merely symbolic and in doing so makes the play an allegory.

As the locus of a trouser role, the divided character literal-Fidelio-cum-figurative-Leonora is sustained in a similar allegorical mode, wandering back and forth between two antipodes, masculine and feminine, single and betrothed, free and bound-up to the point of discovery and consequent rescue. Such a dramatically sustained division transforms a mere deception into allegory. The character of Leonora is not simply a woman in man's clothing but more so a parable of sustained misfortune and courage in the face of lengthy personal

24 Witness Schoenberg's notion that the greater the tonal tyrant's strength at the centre, the greater the resolve and force of the rebellious outlying regions that contest it. Schoenberg, Theory of Harmony, $150-51$.

25See Benjamin, The Origin of German Tragic Drama, 159-67, 183. See also Street, "Superior Myths, Dogmatic Allegories: The Resistance to Musical Unity," 102-18. 
challenge, of faith in times of crisis. It is possible to read Leonora literally as the handmaid of Florestan's fortune, a tool in the rescue plot. But the human irony of Leonora's predicament can hardly be overlooked. Our concern for Leonora is deep, sustained, and human, as deep and as real as our concern for humankind in Doctor Faustus, Everyman, or Endgame.

The second allegorical quality of the role is that of effacement: the literal story, the Fidelio deception, must be entirely "effaced" or eclipsed by the figurative, by the allegory of Leonora. ${ }^{26}$ We must never cease to believe in Leonora. Should we surrender to Fidelio's artifices, not only will the plot fall apart but so too our human concerns, our hopes, and our sense of justice, all of which depend upon Leonora's veracity. Much as we believe in Leonora's truth, so too we ought to believe in the truth of tonality - not the facade of tonal unity but the veracity of tonality as a flawed and tentative enterprise, the outcome of which is literally never beyond doubt.

Tonal theory's sphere of operations is the literal, and its precepts, such as tonality, are interpreted in a literal mode. As theorists, we concern ourselves with notes that we treat literally as the bearers of an entirely musical content, forgetting that musical signs such as notes are conventional and thus both carry and support the structures of convention. Although music theory is embedded with figural devices-with metaphor, symbol, and metonym (dominants that "fall" by fifths thus embodying the primacy of a governing "tonic," which represents the "seat" of tonality), sustained departures into the figural are rare. Exceptionally, Schenker's and Schoenberg's figures are carried out to such a length and with such a necessity, that one might justifiably discover allegory at work.

The allegorical potential of Schenker's narratives is cut short, however, by belief in the absolute and ultimate primacy of tonal centricity and unity. Whatever discursive doubts we have about the veracity of tonality pale ultimately under the power of its central and unifying force. ${ }^{27}$ The division between the closed, the notes as musical content, and the open, the metaphors and similes, is never equal or egalitarian. The playing field is always tilted toward the literal finality of tonality, away from allegory. In essence, our graphs always run straight, our motives lie cooly on the page. And allegory is always closed off thereby, shut down. Tonality, in Schenker's narratives, is ultimately unitary, not divisive, and hence can never give rise to unfettered allegorical exploration.

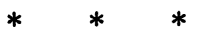

26 "L'allégorie est une proposition à double sens, mais dont le sense propre (ou littéral) s'est entièrement effacé." Todorov, Introduction à la littérature fantastique, 67. Compare Roland Barthes's description of a "second-order semiological system," and a similar process of effacement: meaning turns "suddenly into an empty, parasitical form," "meaning ... empties itself [se vide], it becomes impoverished ..." Mythologies, trans. Annette Lavers (New York: Hill and Wang, 1972), 114-17.

27 There are brief passages that suggest alternatives in Schoenberg's treatises. See the notion of "suspended [schwebende] tonality," in Theory of Harmony, 153, and the oft-cited reference in Structural Functions of Harmony, ed. Leonard Stein (New York: Norton, 1969), 111. 
We have known, at least from Saussure's day onward, that language is conventional and thus discursive. In the wake of post-Saussurian developments, we know that, since no two speakers construe a word with exactly the same conventions, the niceties of conversation and its usage depend upon the shifting wiles of its participants. And we know from critics as diverse as Roland Barthes and Paul de Man that the literary domain of words has often a certain rhetorical and sometimes allegorical content that effaces the literal meaning as captured by a dictionary definition. Barthes's notion of a secondary signification is set forth in his study of myth and accompanying delightfully accurate essays entitled Mythologies. But by way of illustration, let us cite Paul de Man's appreciation of a moment from the television series where Archie Bunker is queried by his ever so literal wife, Edith:

\begin{abstract}
Asked by his wife whether he wants to have his bowling shoes laced over or laced under, Archie Bunker answers with a question: "What's the difference?" ..., his wife replies by patiently explaining the difference between lacing over and lacing under, ... but provokes only ire. "What's the difference" did not ask for difference but means instead "I don't give a damn what the difference is." The same grammatical pattern engenders two meanings that are mutually exclusive: the literal meaning asks for the concept (difference) whose existence is denied by the figurative meaning. ${ }^{28}$
\end{abstract}

To understand the drama of the moment it is absolutely necessary to understand Archie's question as rhetorical. Were we to take the question-as Edith does-at face value, or literally, we would miss entirely a crucial aspect of the episode. In effect, Archie's reply entirely effaces Edith's patient explanation.

Archie's rhetorical question can be seen to embody a discursive potential: there is a marked discrepancy between the literal question and the meaning imputed, so much so that Archie could have substituted any one of a number of questions to the same effect: "What do I care?" "Who gives a damn?" "Why worry?"-all of which could have been taken literally by Edith, whose patient responses were for ever being effaced by her intolerant spouse.

Now this is not a sustained example, although the frequency of such exchanges throughout the television series made it an endearing representative of modern allegory and morals. Edith believes so literally in Archie, in her world, and in the humans that dot it, that she is an eternal wellspring for her unwittingly allegorist husband. For the literary theorist, the two Bunkers are the twins of semiosis and criticism-perennially contradictory, locked in eternal misunderstanding and misreading-the very embodiment of textual interpretation. Along these lines of gendered allegorical coupling let us examine the relation of Leonora to Fidelio.

Like Archie Bunker, Leonora is faced with a literal belief on the part of those around her, belief in Fidelio. Accordingly, everything said to Fidelio must be 
interpreted twice, superficially by Leonora-cum-Fidelio and then by Leonora herself. Of necessity Leonora is suppressed, moved into the realm of the figurative, for to effect the trouser role she must never-not for one momentlet her true self show to those nearest her, and every remark, her every gesture, must sustain the deception. A desperate actress, she must believe her role, immerse herself in Fidelio, and while doing so suppress her own identity, move it over into the figurative and secure it there, lest she slip momentarily and disclose the truth.

A slender thread of belief holds her to this dangerous project. Should she for one moment doubt her integrity-the veracity of Leonora-she will come apart and so too her project of rescue, indeed the whole drama. The drama of the opera is the drama of Leonora. Joseph Kerman describes one object of our concern in Fidelio as Florestan: "It has never occurred to anyone to doubt that Florestan is worthy of Leonora's rescue; if it did, the drama would collapse."29 But perhaps it is Leonora's worth that we ought never to doubt. Florestan in this respect is but a literal plot device; figuratively speaking, he hardly exists. ${ }^{30}$

The operatic audience-being party to Fidelio's masquerade-is not deceived by Fidelio in the way the other characters of the opera are. For the audience, Fidelio is false, this in direct proportion to his onstage fidelity. Leonora, on the other hand, although hidden from the other characters, is to her audience a true character, someone to believe in. But despite this fidelity, throughout the opera until the rescue, hers is a character most fragile, subject to repression and deception, ultimately false to the characters around her on stage, and thus soliciting greater and greater concern from her audience. Unlike Leonora, then, Fidelio mocks "fidelity"; he is true only to Marzellina, Jaquino, and Rocco. Fidelio is a fiction born of necessity, outside the Law (in a sense both literal and Lacanian), and like most fictions he succeeds marvellously for a while in a manner that seems at once both real and uncanny.

Were the character of Fidelio to ascend too high, for whatever reason, the drama would collapse in a sense not unlike Kerman's. Florestan, the real Leonora, indeed the whole rescue project could easily become irrelevant to Fidelio. Carried away by his various small successes, Fidelio could change his mind: perhaps Florestan is not worth it, or the project impractical. Perhaps Fidelio should just walk out of here, claim the need for fresh air, never come back, revert to Leonora ohne Florestan. While Fidelio entails literally a freedom from prison for Florestan, he entails figuratively a freedom, potentially a liberation, for Leonora-a freedom and liberation curtailed by Florestan's rescue and Fidelio's demise. Fidelio-the-fiction is a danger not only to Pizzaro but also to Leonora.

29 Joseph Kerman, Opera as Drama (New York: Vintage, 1956), 97.

30 Speaking within the plot, the identity and condition of the prisoner is an unknown to Leonora and the audience, of course. For all that she (and the audience member) knows, Florestan may have been dispatched, and the rescue project may prove futile, a fact that cannot help but detract from her assurance. See Michael C. Tusa, "The Unknown Florestan: The 1805 Version of 'In des Lebens Frühlingstagen," Journal of the American Musicological Society 46, no. 2 (Summer 1993): 182 n. 12. 
How far could the Fidelio role ascend, were Leonora to harbour one small but earth shattering doubt about Florestan's worth? Were there past infidelities or slights, minor but nagging hurts? Is it possible that Fidelio might usurp the role entirely, given some injustice to Leonora on the part of Florestan prior to his detainment? Is it possible the masculine facade might efface entirely the feminine, and that in another opera entitled Leonora the rescue might have been aborted, the character of Leonora becoming a spectre, a wraith in the developing psyche of Fidelio? These character insecurities hinge around the little word "du," which begins two crucial verses of the "Komm Hoffnung" text, starting the repeated line "O du, für den ich alles trug." Should we doubt for one moment that this "du" is aimed at Florestan, doubt the centripetal force of her attraction to Florestan, a whole set of centrifugal forces are leashed irrevocably. An allegorical second story-Leonora addressing her familiar self as "du"comes into play: "Oh you, for whom I bear this all," becoming "Oh you yourself Leonora, for whom you bear this all." Perched between two tendencies-to believe in Leonora or to believe in Fidelio-the aria "Komm Hoffnung" is an attractive exercise in walking a tightrope.

"Music Lessons," a short story by Bonnie Burnard, one of a group of compelling writers from Saskatchewan, affords us a new perspective on the troublesome character of Leonora and her relationship to Fidelio. The story, told by a young woman on the threshold of maturity, treats of an aging piano teacher moving across the fact of her husband's death into a stage not of grief but reflection-ostensibly a reflection in turmoil, although this is only sketched darkly, as a shadowed world barely comprehensible to the young narrator. While living, the teacher's husband is seemingly indifferent to the piano lessons taking place in the adjacent room. The lessons take on the semiotic medium of a carefully controlled feminine exchange under the auspices of a silent patriarch. Controlled, or at least regulated by his tacit indifference-a governing force of a quality at once banal and frighteningly profound-, the lessons proceed much as lessons should, with the mastery of stipulated tasks and a general acknowledgement of the accepted curriculum, to culminate in the kind of legislated conservatory examination that is, in Canada, both ubiquitous and maddeningly unquestioned.

Upon the husband's death, the tacit bonds controlling this exchange are broken, and the teacher's conduct during the lessons alters dramatically, first to the delight and then the apprehension of the student. As the lessons proceed, the teacher's physical appearance deteriorates dramatically; framed photos appear on the piano, first a portrait of the husband, but this crowded later by older photos of five "lovers" (numbering among them the student's grandfather as a young man). Soon the carefully regulated lesson is abandoned, the teacher leafing idly through old portrait albums, while the student fumbles through ill-prepared pieces on the way to a failed examination. In a curiously wrought conclusion, the student returns uninvited to fulfil one of the household chores that fell to the late husband. This sparks a confrontation between student and 
teacher, which surely constitutes the "music lesson" alluded to by the title. As the narrator, the student, concludes the story:

She came at me with her arms out and though there was no way to tell whether she was going to pound me or lean on me or hug me, I could not have run. Her hands were firm on my shoulders; the sound she made was loud and brutal and almost young. ${ }^{31}$

Let us consider Leonora and the aging piano teacher. What would Leonora's fate be, some twenty years after the rescue, with the premature passing of Florestan, let us say, from the effects visited upon his constitution by his confinement? Let us envision Florestan as a husband largely indifferent over the course of those twenty years to a series of exchanges between an aging Leonora and an eternally young Fidelio-a memory trace, unruly, forever champing on the threshold of the second act, ceaselessly demanding lessons, crying: "What is the meaning of my life to yours Leonora? What do I signify?" What would the death of Florestan, the regulating influence that keeps this ungainly youth Fidelio in some kind of measure, what would the passing of this man set loose in Leonora? What turmoil would his death unleash? Would the death of the man bring about a transformation in Leonora's demeanour toward Fidelio-unregulated, deteriorating, riddled with visions of ancient and illicit love? Would Leonora sing again the aria "Komm Hoffnung" but now (to quote Burnard's young narrator) in a voice "loud, brutal, and almost young"? There is an allegory in Fidelio, and it is not necessarily tied by devotion to Florestan.

Allegories. Where are they to be found in the enterprise of music theory?

Tonality-especially as embodied in tonal centricity and tonal unity-has oft been represented as a fait accompli, despite the many accounts that trace the development of certain "kinds" of tonality as a long and complicated process of construction manifold in its results. ${ }^{32}$ Accordingly, tonality is considered a natural law discovered, like the law of gravity, first at the hands of composers, then by theorists. Enter a theorist-practitioner of the ilk of Arnold Schoenberg, that errant child intent on pounding square pegs into his predecessors' round holes. As Schoenberg confessed:

I do not, as apparently all theorists before me have done, consider tonality an eternal law, a natural law of music ... Tonality is a formal possibility that emerges from the nature of tonal material, a possibility of attaining a certain completeness or closure by means of a certain uniformity. ${ }^{33}$

31 Burnard, "Music Lessons," 18.

32 "Loyalty to a tonic, in the broadest sense of the word. One of the most striking phenomena of music is the fact that, throughout its evolution-in non-Western cultures, in Gregorian chant, and in harmonized music-practically every single piece gives preference to one tone (the tonic), making this the tonal center to which all other tones are related." Willi Apel, Harvard Dictionary of Music, 2nd ed. (Cambridge, Mass.: Belknap Press of Harvard University Press, 1969), s.v. "Tonality."

33. Schoenberg, "Problems of Harmony," in Style and Idea, 278. 
"By means of a certain uniformity"- tonality works by presenting a smooth uniform face. Being artificial, a product of humankind with its flaws and variances, tonality does not, in and of itself, possess such a face. It can only effect a masquerade of smoothness in a musical work by means of uniformity.

Tonality is not an eternal natural law. This little Schoenbergian wedge opens up a fateful crack in the edifice of tonality-as-centricity-and-unity, a crack which, left of its own accord, would tear the whole thing apart. To rephrase Kerman's appraisal of the fragile thread that holds Fidelio together: it has seldom occurred to anyone to doubt that the uniform effect of tonality is worthy of the theorists' laboured devotions, for if it did, the drama of analysis would collapse.

Schoenberg, ever equivocal about tonality, defined it as the submitting of all events to the referential power of a tonic, a phrase that has a curious semiotic ring to it:

[Tonality] has always been the referring of all results to a centre, to an emanation point of tonality, which rendered important service to the composer in matters of form. All the tonal successions, chords and chord-successions in a piece achieve a unified meaning ["einheitliche Bedeutung"] through their definite relation to a tonal centre and also through their mutual ties. ${ }^{34}$

Tonality is a procedure of naming, of reckoning, of defining events in light of one unequivocal and unitary point of reference, of subjecting all events to one central authority - one Law, in a curious semiotic sense reminiscent of gender, Lacan, and the tacit husband in Burnard's story.

It is not easy to doubt tonal centricity and unity as preconditions for musical semiosis, tonality being so often taken unconditionally (to which the fact that tonality is so seldom defined firmly attests). But Schoenberg did, after all, offer a thin wedge, a shadow of a doubt. To doubt the primacy of tonality is to put Burnard's portraits of ancient lovers on the piano; to doubt tonality is to open up an unsettling discourse about fidelity.

In literal truth, the tonality of the aria "Komm Hoffnung" is banal, offering little food for thought. Given the tonal yardsticks proffered us by Schoenberg and Schenker, the most remote tonal events-distant tonal regions or far-reaching foreground diminutions-occupy a very small part of the aria proper and are nowhere as remote, speaking in tonal terms, as one might expect from Beethoven. The tonal uniformity seems a banal facade, bathetic, especially if one brings to mind the importance of the aria and the tensions drawn in Leonora-cum-Fidelio.

If our initial, face value impression of the aria's tonality is one of irrelevance to the libretto, a second, figurative impression affords us a dramatic correction. While the tonality of the aria proper is not particularly noteworthy (set almost

34 Ibid. 
entirely in E major, with few asides into related keys or regions of the tonality), nested within the aria lies a brief passage that poses problems for the conception of tonality (both our conception and, as I shall suggest, that of theorists in Beethoven's time and after). This passage begins with the first appearance of the text "O du, für den ich alles trug," and concludes with the repetition of "könnt' ich zur Stelle dringen." The passage is framed by E major, but within it are four tonicizations: A major and its relative, F-sharp minor, and G major and its relative, $\mathrm{E}$ minor. The A major/F-sharp minor passage is repeated sequentially with variation down the interval of a second in $G$ major/E minor, coinciding with a repetition of the dramatically crucial line noted above: "Oh $\mathrm{du}$, für den ich alles trug." The arrangement of the tonicizations framed by $\mathrm{E}$ major is as follows, aligned with the repetition of the text:

$\mathrm{O}$ du, für den ich alles trug, könnt' ich zur Stelle dringen, wo Bosheit dich in Fesseln schlug und süssen Trost dir bringen! $\mathrm{O}$ du, für den ich alles trug, könnt' ich zur Stelle dringen, wo Bosheit dich in Fesseln schlug, könnt' ich zur Stelle dringen! [from E major]

A major

F-sharp minor

G major

E minor

[to E major]

Tonality we define as the clear and consistent relation of harmony to a unitary tonal centre. It follows that obscurity and inconsistency must pose problems for tonality, be it the literal tonality of a given musical work, or tonality abstracted from individual instance as a figural representation of the way musical things work. In the literature of tonality, theorists speak of a rupture between diatonic and chromatic systems. ${ }^{35}$ Discerning cracks of this sort in the tonal edifice, theorists are quick to cover them over, to limit disruption, and in doing so they reveal the extent and limits of their ideology. ${ }^{36}$ Disruption need not be taken as threatening, however, for ruptures give rise to a secondary content - that of allegory.

There are at least two problems posed in the aria: one by an implicit sequence, the other by certain diminished-seventh chords that appear in the passage. Emblematic of the obscurity and inconsistency implicit in semiosis in general and literature in particular, these tonal problems result in the kind of figurative counterpart to literal meaning that we know of as allegory. What kind of allegorical structure is at work in the problems of tonal relation in this musical passage?

35 Schenker speaks of a number of systems-natural, artistic, diatonic, and a system of "chromatic change"-in Harmony, part 2, section 2, chapter 4, pp. 288-301. See also Schoenberg, Theory of Harmony, 313-14.

36Schenker suggests that chromaticism serves the diatonic system as a strengthening form of exercise, but this must never exceed the goal of tonicization. See Harmony, 289. 
The sequential problem is a problem of logic within a Beethovenian style, stated simply as follows: if A major to F-sharp minor is a Beethovenian model, and $\mathrm{G}$ major to $\mathrm{E}$ minor its sequence carried out a whole tone lower, we might expect yet another sequence a whole step lower, F major and D minor-remote tonal regions in E major (the Neapolitan and its relative minor) ${ }^{37}$ This problem is really without solution: break the sequence, and one violates its logic; continue the sequence, and one puts at risk the tonality. Beethoven chooses the former path, but not after establishing a problem he might otherwise have avoided.

No doubt this literal problem of sequential and tonal consistency serves the libretto well. At this moment in the drama, the discrepancy between the Fidelio facade and the truth of Leonora's predicament is most apparent, while in the harmony centripetal and centrifugal tonal tensions are brought to a head. Leonora's rescue project is unrealizable in the immediate future, and she must return to projecting Fidelio's unitary facade, much as the harmony is constrained to return to the tonal centre. Opposing gravities meet, then, in character and in tonal terms: Leonora is allowed one brief appearance, before Fidelio rises again; tonal liberty is allowed one brief suggestion, before tonal centricity shuts it down.

Like Leonora's little repeated "du," the sequential problem opens up doubts in the edifice of tonality, thus revealing an allegorical second content. The tonality of this aria is not about unity; the bland tonality of the passages prior to the sequence is effaced by it. The resumption of $\mathrm{E}$ major is as much a facade as Fidelio, and should we lose sight of this tonal facade, we lose sight of the tonal drama. The modulating harmonic sequence challenges the very concept of tonal unity, and in doing so calls tonal unity to exercise. Problems of this sort are thresholds crossed: one can never return to the same hitherto unproblematic space; one can never recreate exactly the same tonal balance, once centrifugal forces have been unleashed. Without question, the aria will return to tonic, and the tonality close on its central pillar as the aria ends. But the discourse - the questioning of tonality-unleashed by these problems will aggravate and unsettle any such closure. The centrifugal sequence suggests other tonalities, other narratives, and these remain like nagging doubts. In an allegorical sense, the tonic harmony with which the aria begins is far more closed and final than the tonic with which the aria ends.

Our second tonal problem is the sustained fortissimo chord that sets the repetition of the phrase "wo Bosheit dich in Fesseln schlug." In breaking the sequence, the harmony settles here upon a diminished seventh chord applied to the dominant of $\mathrm{E}$ minor. In crude terms, the diminished seventh has been called a fickle changeling by theorists since Beethoven's day. ${ }^{38}$ It is a com-

37 The sequence is carried out elsewhere. Compare for example, the third movement of the A major Piano Sonata, op. 101, bars 14-16. See also Schenker's analytic elucidation published as Beethoven, Die letzten Sonaten: Sonata A Dur Op. 101 (Vienna: Universal Edition, 1972), 52-57.

38The multiple meaning of this chord-its Mehrdeutigkeit-is addressed in Joseph Drechsler, Harmonie und Generalbass-Lehre, 2nd ed. (Vienna: Haslinger, [1820]), 94-95; Abbé Georg Joseph Vogler, Handbuch zur Harmonielehre und für den Generalbass nach den Grundsätzen der Mannheimer Tonschule (Prague: K. Barth, 1802), 101-10; Fétis, Traité complet de la théorie et de la pratique de l'harmonie ..., 177-83; Johann Philipp Kirnberger, The Art of Strict Composition [1771], trans. David 
monplace in tonal theory that diminished sevenths can be reinterpreted enharmonically in at least four keys. This particular diminished seventh leads to $\mathrm{E}$ minor, the tonally unproblematic parallel minor of the aria's $\mathrm{E}$ major tonal centre. But the chord could have been reinterpreted in other keys that lie successive minor thirds above e: G, B-flat, and D-flat (or conversely C-sharp, a minor third below). Each of these reinterpretations would present a crisis for a tonality centred largely on E major, this coming at the very moment of sequential instability. Like Leonora's pivotal "du," should the centripetal E-minor reading of this chord be doubted for one moment, all pretence of tonal unity would be effaced by problematic second readings in those fractious keys-G, B-flat, and D-flat.

Beethoven's solution to the literal problem of the diminished seventh is blunt-return immediately to the tonic. But here the usage of this enharmonically unstable chord opens up an unsettling discourse about adherence to one tonal centre, about the possibilities of non-adherence, about disobedience.

The discourse is played out in the theoretical literature of Beethoven's time and later, in a tone often prophetic and hence allegorical. Witness Fétis for whom the enharmonic possibilities of the diminished chord and others like it ushered in a new "order" while introducing yet another malignancy with which to satiate musical emotions. Fétis's discussion of diminished-seventh enharmonie concludes with the following assessment of its perils:

In music the introduction of multiple tendencies or tonal attractions [shared by] apparently identical notes has created a new order of harmonic and melodic givens, which I have named the "pluritonic order." This is the third period of the art [of music]. Independently of the force of expression introduced by this new organ, it has added (to other emotions produced by music) the sensation of surprise, a sensation so much the more sought in the present state of society since one of the maladies of the human species, in our time, is the satiety of the simple emotions. ${ }^{39}$

And consider Moritz Hauptmann in the same vein:

For so far as this way of modulation [by means of the diminished seventh chord] is believed to be authorised in assuming as identical, because of outward nearness, what is inwardly quite different and without relationship, it is as it were tainted with untruth, and we cannot rank the constructions, whose explanation has to be sought in such enharmonic changes, with those which depend upon an organic union. They have not a natural life, and exist only in the turbid element of the inaccuracy of tempered intonation. ${ }^{40}$

\footnotetext{
Beach and Jürgen Thym (New Haven: Yale University Press, 1982), 299-305; Gottfried Weber, Versuch einer geordneten Theorie der Tonkunst (Mainz: B. Schott, 1817-21), 2:72-80; Simon Sechter, Die Grundsätze der musikalischen Komposition (Leipzig: Breitkopf und Härtel, 1853), "Erste Abtheilung: Die richtige Folge der Grundharmonien, oder vom Fundamentalbass und dessen Umkehrungen und Stellvertreten," section 5, pp. 210-15.

39Fétis, Traité complet de la théorie et de la pratique de l'harmonie ..., 183.

40Moritz Hauptmann, The Nature of Harmony and Meter, ed. and trans. W. E. Heathcote (London: Swan Sonnenschein, 1893), 166-67.
} 
As well as Schoenberg:

The diminished seventh chord provoked this movement [toward new paths and harmonies], which cannot stop before it has fulfilled the will of nature, and not before we have reached the greatest possible maturity in the imitation of nature: so that we can then turn away from the external model and more and more toward the internal, toward the one within us ... The inclusion of so many relationships [implicit in the diminished seventh chord] in itself has already turned tonality into a phenomenon of greater activity. It now contains more unrest, in light of which a more vigorous action is no longer so inappropriate. ${ }^{41}$

Just what is at stake here to provoke such turns to the figurative? All three authors would seem to agree that the basis of tonality, seemingly so confident and firm, is in truth on shaky ground when it comes to this chord and others like it. The threat is that of duplicity, that a chord might have several meanings or faces in a tonal drama, and exploiting these facades will be the ruin of tonality. The threat applies not only to diminished seventh chords but even to triads, according to Schenker. Its too drastic exploitation is morally reprehensible:

In those cases, however, where the composer unmistakably reveals his intention to ruin the diatonic system, we have not only the right but, even more, the moral duty to resent the deceit against our art and to expose the lack of artistic instinct which manifests itself here even more drastically. ${ }^{42}$

In short, this diminished seventh chord and other chords like it bring out a suspicion of the propriety of the tonal system, and for the theorists cited and others such a suspicion is dramatically unsettling. That tonality itself, the pillar of our analytic method, should harbour such difficulties, casts the whole enterprise in the uneasy light of a deception. There are dissolute tendencies in tonality, tendencies by which some theorists are driven ideologically to exertions.

Although Beethoven's resolution to the tonal centre is smooth and seemingly natural in "Komm Hoffnung," the tonality is changed irrevocably by this diminished seventh chord, as it was by the sequence. Behind the Leonora of the aria's final cadence stands a crowd of potential Leonoras-the dutiful wife, the brave rescuer, the person coming to discover hidden strengths and resources, the widow crying in a manner "loud and brutal and almost young." So too, behind the facade of tonal unity at the end of the aria lies a wealth of tonalities, from the close and ruly to the distant and fractious.

In essence, the aria's tonality presents us with a veneer of tonal coherence, like the smooth facade of Fidelio. It clothes the human uncertainty, implicit in the project of tonality, in apparent unity. But we need not take this at face value.

41 Schoenberg, Theory of Harmony, 239-40.

42Schenker, Harmony, 290. 
The fabric of tonality is torn and patched, worn and seamed, with bare spots and stains by 1805 . To overlook this is, again, to mistake Fidelio for the truth and to lose sight of the drama of tonality.

Surely at the end of the twentieth century, one can no longer take tonal centricity and unity at face value-literally. It is a fiction, albeit constructed with the greatest ability by a composer such as Beethoven and theorists like Fétis, Schenker, and Schoenberg, among others. Following the rubric of allegorical reversal, tonality is a desperate enterprise, skilled at deception, overlaying its fissures with a veneer of formal coherence and unity.

The discontinuities of sequence and chord highlighted above represent in concrete musical terms the rich allegorical content of tonal theory. Problems, splits, and fissures of this sort are commonplace in musical scores. They should be ubiquitous to those of us trained in discovering tonal unity and coherence, for they are the remote passages, the difficult and fractious parts of our analyses. Rare is the musical work that does not reveal discontinuities. ${ }^{43}$ Rare too is the analysis that treats them as anything other than surface or enriching phenomena. In doing so, we overlook a properly humanistic aspect of our discipline-to teach us about ourselves, our discontinuities, our contradictions, and ultimately our ideologies. Being part of a humanistic enterprise, this search for discontinuity, for slips, for rereadings, need not denigrate the accomplishment of a Beethoven, a composer eminently human. Such a project need not denigrate at all, except in the eyes of the absolutist who holds music in a kind of pristine and ultimate condition remote from human contradiction, for whom tonality is unproblematic, a literal truth, devoid of figure and thus of allegory.

\begin{abstract}
Tonality has both a literal and a figurative or allegorical aspect. Tonal unity, a commonplace among much current music theory, is a superficial entity, a literal facade beneath which lies a sustained and discursive domain, where tonality is made and remade in a continual process of fracturing and reinterpretation. Like the frought persona of Beethoven's Leonora-cum-Fidelio, the tonality of the aria "Abscheulicher! ... Komm Hoffnung ..." defies analysis as a unified structural whole. Like the behaviour of the piano teacher in Bonnie Burnard's short story "Music Lessons," the conventional behaviour of tonality can be seen to crack and buckle in the aria, albeit only briefly, before it is smoothed over and fractious elements suppressed behind a facade of the calibre of a Fidelio.
\end{abstract}

43 Dependent on the vagaries of repetition through time, music is perhaps the art most given to a formal frailty. See de Man, Blindness and Insight, 126-33. 